University of Nebraska - Lincoln

DigitalCommons@University of Nebraska - Lincoln

Virology Papers

Virology, Nebraska Center for

February 2007

\title{
Effects of turnip crinkle virus infection on the structure and function of mitochondria and expression of stress proteins in turnips
}

James A. Blake

University of Nebraska-Lincoln

Kit W. Lee

University of Nebraska-Lincoln

Thomas Jack Morris

University of Nebraska-Lincoln, jmorris1@unl.edu

Thomas Elthon

University of Nebraska-Lincoln, telthon1@unl.edu

Follow this and additional works at: https://digitalcommons.unl.edu/virologypub

Part of the Virology Commons

Blake, James A.; Lee, Kit W.; Morris, Thomas Jack; and Elthon, Thomas, "Effects of turnip crinkle virus infection on the structure and function of mitochondria and expression of stress proteins in turnips" (2007). Virology Papers. 121.

https://digitalcommons.unl.edu/virologypub/121

This Article is brought to you for free and open access by the Virology, Nebraska Center for at DigitalCommons@University of Nebraska - Lincoln. It has been accepted for inclusion in Virology Papers by an authorized administrator of DigitalCommons@University of Nebraska - Lincoln. 
Published in Physiologia Plantarum 129:4 (2007), pp. 698-706; doi 10.1111/j.1399-3054.2006.00852.x

Copyright ( 2007 Physiologia Plantarum; published by John Wiley \& Sons. Used by permission.

http://www3.interscience.wiley.com/journal/118510326/home

Submitted September 6, 2006; revised October 29, 2006; published online February 7, 2007.

\title{
Effects of turnip crinkle virus infection on the structure and function of mitochondria and expression of stress proteins in turnips
}

\author{
James A. Blake, Kit W. Lee, T. Jack Morris, and Thomas E. Elthon* \\ School of Biological Sciences, University of Nebraska, Lincoln, NE 68588-0666, USA \\ * Agronomy and Horticulture Department, Center for Biotechnology, Plant Science Initiative, School of Biological Sciences, \\ E249 Beadle Center, University of Nebraska-Lincoln, Lincoln, NE 68588-0665, USA \\ Corresponding author-T. E. Elthon, email telthon1@unlnotes.unl.edu
}

\begin{abstract}
We have investigated the effect of turnip crinkle virus (TCV) infection on mitochondrial structure and function in turnips (Brassica rapa cultivar "Just Right"). TCV infection resulted in plants with small, mottled leaves with severely crinkled edges, and in a $46 \%$ reduction in storage root mass. TCV infection resulted in specific vesicularization of mitochondrial outer membranes where TCV replication is thought to occur, with no apparent affect on other cellular membrane systems. Immunoblot analysis of mitochondrial proteins from storage roots indicated that the TCV p28 protein, which is essential for viral replication, was associated with mitochondria and that mitochondrial heat shock protein 70 and cpn60 levels increased upon TCV infection. Isolation of mitochondrial outer membranes further showed TCV p28 protein enrichment in the outer membrane as compared with total mitochondrial proteins or total cellular proteins. Analysis of mitochondrial electron transport chain activities indicated that TCV infection resulted in a 54\% decrease in exogenous $\mathrm{NADH}$-dependent oxygen uptake and a $8 \%$ decrease in succinate-dependent oxygen uptake. Together these results indicate that TCV infection induces a stress response in mitochondria and a reduction in the ability of mitochondria to supply adenosine 5'-triphosphate to the cell.
\end{abstract}

Abbreviations: ATP, adenosine 5'-triphosphate; HSP70, heat shock protein 70; I, infected turnips; IgG, immunoglobulin G; Mi, whole miochondia; NADH, nicotinamide adenine dinucleotide (reduced); OM, outer mitochondrial membranes; SDS-PAGE, sodium dodecyl sulfate-polyacrylamide gel electrophoresis; TCV, turnip crinkle virus; TP, total cellular protein.

\section{Introduction}

The number and cellular location of viral encoded proteins involved in the replication of positive-sense RNA viruses varies considerably. RNA viruses with very small and simple genomes, such as members of the Nodaviridae family (flock house virus), encode only a single replicase associated subunit. Among the smallest and genetically least complex of the RNA plant viral genomes are members of the family, Tombusviridae. Viruses in this family, such as turnip crinkle virus (TCV) and toma- to bushy stunt virus, encode two polypeptides, the larger of which is a readthrough product of the smaller subunit. Together these comprise the functional replicase complex that may also include several, as yet uncharacterized, host proteins (Nagy and Pogany 2000). A majority of RNA viruses, including members of these two families, induce similar types of alterations in host membrane morphology in infected plant and animal cells, suggesting that the replication apparatus of eukaryoteinfecting RNA viruses may have evolved from a common ancestor (Buck 1996). The common theme shared 
by most RNA viruses is the general dependence of RNAvirus replication on an array of intracellular membranes. Ultrastructural studies of insect cells infected with two related alphanodaviruses (a genus in the Nodaviridae family), nodamura virus and boolarra virus, showed that the disappearance of mitochondria in infected cells correlating with the appearance of vesiculated bodies that contained RNA (Garzon et al. 1990). These morphological studies resulted in speculation that the newly formed membranous structures were involved in viral replication, probably providing necessary structure to organize the replication complex and/or energy for replication. Similar membranous-like structures associated with peroxisomes and mitochondria have been reported in plant cells infected with members of the Tombusviridae (Rubino and Russo 1998).

Schwartz et al. (2002) suggested that all classes of viruses replicating through RNA intermediates, including positive stranded RNA viruses, reverse transcribing viruses and double stranded RNA viruses, sequester their RNA templates in a multisubunit core that directs synthesis of the RNA or DNA replicative intermediate from which the virus genome is subsequently replicated. It was suggested that this replication strategy helps to provide an additional level of template specificity in addition to helping to retain the negative strand products for template use. It was also proposed that the sequestering of the replication machinery in membranous vesicles also reduces exposure of the double stranded RNA replicative intermediate structure to surveillance by RNA interference-based host defense mechanisms.

We have previously examined the genome structure and determined the viral proteins involved in the replication of TCV. The TCV genome encodes five proteins, two of which are associated with the replication apparatus and are translated from the full-length genomic RNA (Hacker et al. 1992). These include a 28-kDa N-terminal polypeptide from the first open reading frame of unknown function (p28), and a readthrough product of 88 $\mathrm{kDa}$ that is the RNA polymerase (p88). Two subgenomic RNAs are produced as a product of the replication process. They include a $1.7-\mathrm{kb}$ subgenomic RNA that encodes two movement proteins of 8 and $9 \mathrm{kDa}$, and a 1.45-kb subgenomic RNA that encodes the 38-kDa viral coat protein (p38).

Multivesicular bodies presumably derived from mitochondria have been described in plant cells infected with several different members of the Tombusviridae, including carnation Italian ringspot tombusvirus, and the carmoviruses, saguaro cactus virus as well as TCV (Russo and Martelli 1982, Russo et al. 1981). Furthermore, it was shown that in infections of cymbidium ringspot tombusvirus, the peroxisome derived multivesicular bodies occurred before the virus particles appeared in the cytoplasm (Russo et al. 1981). These multivesicular bodies were shown to contain fibrillar structures that disappeared upon treatment with RNase at low salt, prompting the conclusion that the multivesicular bodies contained double stranded RNAs associated with virus replication taking place at the periphery of the vesiculated bodies (Rubino and Russo 1998, Russo et al. 1981). TCV replication has been subsequently shown to be associated with a membranous pellet that was shown to be capable of specifically transcribing full-length TCV RNA in vitro, although the composition and cellular location of the viral-specific RNA complex were not determined in that study (Song and Simon 1994). Subsequent work further characterized the TCV replication complex and demonstrated that it can function in vitro, although the composition of the replication machinery in those extracts was not determined (Nagy and Pogany 2000, Rajendran et al. 2002).

Confirmation that the p28 subunit has an essential role in replication came from our previous study showing that p88 readthrough mutants of TCV, incapable of transcribing p28, could not replicate in vivo (White et al. 1995). Importantly, replication function could be restored by coinoculation of mutants into protoplasts that were able to produce the $\mathrm{p} 28$ and p88 proteins independently. This result established the requirement for both proteins in the replication complex, and suggested to us that detection of the $\mathrm{p} 28$ protein, which is present in 10-fold excess of the p88 protein in vivo (Li 1996), might provide a facile way to determine the cellular location of the replication complex.

In this article, we have focused our attention on localizing the p28 protein in an effort to determine its role in the replication complex. To accomplish this, we have isolated mitochondria from infected turnips and unambiguously demonstrated that p28 is associated with mitochondrial membranes. Using electron microscopy, we were able to show that vesicular bodies in TCV-infected tissue were derived from outer mitochondrial membranes. Further, we confirmed the specific association of p28 with isolated outer mitochondrial membranes using p28-specific antibodies. We also provide evidence that viral infection has a detectable impact on both mitochondrial function, and the expression of known mitochondrial stress proteins.

\section{Materials and methods}

\section{Growth and inoculation of turnip plants}

Turnips (Brassica rapa cultivar "Just Right") were grown in a greenhouse maintained under 16-h light (20$\left.26^{\circ} \mathrm{C}\right)$ and 8 -h dark $\left(14-20^{\circ} \mathrm{C}\right)$ cycles for a minimum of 30 days. Turnip seedlings were inoculated at the four- 
to five-leaf stage with buffer [100 $\mathrm{mM}$ potassium phosphate, $1 \%(\mathrm{w} / \mathrm{v})$ Celite] alone (mock) or with plant sap containing virus (infected).

\section{Electron microscopy of turnip leaves}

Leaf segments (mock and infected) were fixed in $4 \%(\mathrm{v} /$ v) glutaraldehyde in $0.1 \mathrm{M}$ phosphate buffer $(\mathrm{pH} 7.2)$ at room temperature for $4 \mathrm{~h}$ and postfixed in $2 \%(\mathrm{w} / \mathrm{v})$ osmium tetroxide for $1 \mathrm{~h}$. Samples were dehydrated in a graded ethanol series [25, 50, 75, 90 and $100 \%,(\mathrm{v} / \mathrm{v})$ 20 min each] and propylene oxide and then infiltrated in Epon 812. Epon blocks were polymerized at $60^{\circ} \mathrm{C}$ for 2 days. Thin sections were cut on a LKB Ultrotome III (Piscataway, NJ) and contrasted with uranyl acetate and lead citrate. Grids were examined with a Hitachi $\mathrm{H}$ 7500 electron microscope (Schaumburg, IL) at $60 \mathrm{kV}$.

\section{Isolation of mitochondria, mitochondrial outer membranes and total cellular proteins}

Turnip root tissue ( $240 \mathrm{~g}$ ) was diced to approximately 1 $\mathrm{cm}$ slices with a food processor, and then blended to a pulp with a razor blade-fitted blender for $2 \mathrm{~s}$ in $800 \mathrm{ml}$ of grinding media [350 mM mannitol, $30 \mathrm{mM} 3-(\mathrm{N}-$ morpholino)propane sulfonic acid, $1 \mathrm{mM}$ ethylenediaminetetraacetic acid, $0.136 \%(\mathrm{w} / \mathrm{v})$ l-cysteine, $0.72 \%$ $(\mathrm{w} / \mathrm{v})$ polyvinylpolypyrrolidone, $\mathrm{pH}$ 7.2]. The filtrate was passed through a wire mesh, squeezed through one layer of muslin cloth and put through differential centrifugation to collect whole mitochondria, as described earlier (Hayes et al. 1991). Mitochondria were either stored in suspension media [250 $\mathrm{mM}$ sucrose, $30 \mathrm{mM} 3$ ( $\mathrm{N}$-morpholino)propane sulfonic acid, $\mathrm{pH} 7.2]$ at $-80^{\circ} \mathrm{C}$ or used fresh to obtain submitochondrial fractions or for oxygen uptake measurements. The cytosolic fraction of turnip roots was isolated and concentrated as described earlier (Lund et al. 1998).

Mitochondrial outer membranes were isolated with a modified protocol, originally used for potato tubers (Heins et al. 1994). Two mitochondrial preparations were pooled and washed twice in $5 \mathrm{ml}$ of wash buffer [25 mM 3-(N-morpholino)propane sulfonic acid, $0.4 \mathrm{M}$ mannitol, $1 \mathrm{mM}$ ethyleneglycol-bis (ether $\beta$-aminoethyl) $N, N, N^{\prime}, N^{\prime}$-tetraacetic acid, $2 \mathrm{mM}$ phenylmethylsulfonyl fluoride, $\mathrm{pH}$ 7.2]. The washed mitochondria were ruptured osmotically in $7.5 \mathrm{ml}$ of swelling/resuspension buffer ( $5 \mathrm{mM}$ potassium phosphate, $\mathrm{pH}$ 7.2) for $10 \mathrm{~min}$ on ice. Another aliquot of $5 \mathrm{ml}$ of resuspension buffer was added, and incubated for a further $5 \mathrm{~min}$ on ice. The swollen mitochondria were sheared by hand with a glass potter homogenizer (five compressions on ice), layered on a $15 / 32 / 60 \%(\mathrm{w} / \mathrm{v})$ sucrose gradient in gradient buffer $[1 \mathrm{mM}$ ethylenediaminetetraacetic acid,
$1 \mathrm{~m} M$ phenylmethylsulfonyl fluoride, $10 \mathrm{mM} 3-(\mathrm{N}$ morpholino)propane sulfonic acid/KOH, $\mathrm{pH}$ 7.2] and centrifuged for $1 \mathrm{~h}$ at $134000 \mathrm{~g}$ in a Sorvall TH-641 rotor (Asheville, NC). The band at the $15 / 32 \%(\mathrm{w} / \mathrm{v})$ sucrose interface was collected and contained the mitochondrial outer membrane fraction. This fraction was adjusted to $50 \%$ sucrose in gradient buffer, and used to form the bottom layer of a second gradient $[0 / 32 / 50 \%$ $(\mathrm{w} / \mathrm{v})$ sucrose], which was centrifuged for $\geq 16 \mathrm{~h}$ at $125000 \mathrm{~g}$ in a TH-641 Sorvall rotor. The 0/32\% (w/v) sucrose interface was taken, and the membranes were pelleted at $160000 \mathrm{~g}$ in a Sorvall T-865.1 rotor for $1 \mathrm{~h}$. The membranes were resuspended in suspension media and stored at $-80^{\circ} \mathrm{C}$.

Total cellular proteins were obtained from turnip leaves by grinding in liquid nitrogen and then boiling the sample in $1 \times$ sodium dodecyl sulfate-polyacrylamide gel electrophoresis (SDS-PAGE) sample buffer [41.7 $\mathrm{mM}$ Trizma $\mathrm{HCl}, 2 \%(\mathrm{w} / \mathrm{v}) \mathrm{SDS}, 2 \%(\mathrm{v} / \mathrm{v}) \beta$-mercaptoethanol, $10 \%(\mathrm{v} / \mathrm{v})$ glycerol] for $1 \mathrm{~min}$. The suspension was then centrifuged at $13800 \mathrm{~g}$ for $1 \mathrm{~min}$ in an Eppendorf 5415 microfuge (Hamburg, Germany) before loading on a SDS-PAGE gel.

\section{Gel electrophoresis}

SDS-PAGE gels were prepared and electrophoresed in a Bio-Rad Mini-Protean II apparatus (Hercules, CA) as described previously (Elthon and McIntosh 1986). Fifteen percent $(\mathrm{w} / \mathrm{v})$ acrylamide resolving gels and $5 \%$ $(\mathrm{w} / \mathrm{v})$ acrylamide stacking gels were utilized. Two-dimensional SDS-PAGE gels were prepared as previously described (Lund et al. 1998) with 15\% (w/v) acrylamide resolving gels and no stacking gel. Molecular masses were approximated using two sets of commercial standards, low molecular weight standards from Bio-Rad and prestained rainbow markers from Amersham (Piscataway, NJ).

\section{Polyclonal antibodies, monoclonal antibodies and immunoblotting}

Polyclonal antibodies against TCV p28 protein were raised in rabbits against a $\beta$-galactosidase/p28 protein fusion protein expressed from a pUC expression vector in Escherichia coli (Wei 1990). The antibody was purified from serum with an AminoLink Plus Immobilization Kit affinity column (Pierce, Rockford, IL) coated with a Histidine Patch-Thioredoxin (Invitrogen, Carlsbad, CA)/p28 fusion protein. The p28 fusion protein used for antibody purification was produced using the pBAD/ thio-TOPO expression vector (Invitrogen). Polyclonal antibodies against TCV coat protein were prepared as previously described (Wei 1990). Monoclonal antibod- 
ies against heat shock protein 70 (HSP70), cpn60 and the alpha subunit of the adenosine $5^{\prime}$-triphosphatase (ATPase) were previously described (Lund et al. 1998). Monoclonal antibodies to porin were prepared as in Lund et al. (1998). Polyclonal sera raised to an overexpressed fusion protein of maize enolase was a gift from Dr. D.T. Dennis (Queens University, Kingston, Ontario, Canada).

Detection of proteins was carried out using immunoblots probed with various antibodies. Proteins were transferred to nitrocellulose support as described before (Elthon and McIntosh 1986). Immunoblots were developed using either goat anti-mouse immunoglobulin G (IgG) antibodies conjugated with alkaline phosphatase (Sigma A-5153, St. Louis, MO) or with the electrochemical luminescence protocol (Amersham) using sheep antimouse $\lg \mathrm{G}$ or donkey anti-rabbit IgG antibodies conjugated with horseradish peroxidase. Success of protein transfer to blots was visualized by staining with $0.2 \%$ $(\mathrm{w} / \mathrm{v})$ Ponceau $\mathrm{S}$ in 3\% (w/v) tricholoracetic acid for $30 \mathrm{~s}$ followed by rinsing with distilled water. The blots were fully destained prior to antibody probing by washing with phosphate-buffered saline $\left(10 \mathrm{mM} \mathrm{NaH}{ }_{2} \mathrm{PO}_{4}\right.$, $150 \mathrm{mM} \mathrm{NaCl}, \mathrm{pH}$ 7.2) containing 0.3\% (v/v) Tween-20. Nonlinear Dynamics TotalLab Software (Durham, NC) was used for quantification of probed blots.

\section{Analysis of mitochondrial function}

Mitochondrial electron transport chain activities were measured polarographically using a Rank Brothers oxygen electrode (Rank Brothers, Ltd., Cambridge, UK) as described by Heckman et al. (2002). Isolated mitochondria were resuspended in an osmotically stable reaction medium [30 mM 3-( $\mathrm{N}$-morpholino)propane sulfonic

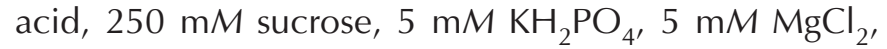
$0.1 \%(\mathrm{w} / \mathrm{v})$ bovine serum albumin, $\mathrm{pH} 7.2]$ to measure exogenous nicotinamide adenine dinucleotide (reduced) (NADH)- and succinate-dependent oxygen uptake. Exogenous NADH-dependent oxygen uptake was initiated with the addition of $1 \mathrm{mMNADH}$. For succinate-dependent oxygen uptake, $1 \mathrm{mM}$ adenosine triphosphate was added prior to addition of $10 \mathrm{mM}$ succinate. Potassium cyanide $(1 \mathrm{mM})$ was added to estimate the capacity of the alternative pathway. The reaction temperature was held at $25 \pm 1^{\circ} \mathrm{C}$ with a LKB 2219 Multitemp II Thermostatic Circulator.

\section{Results}

The infection of turnip plants with TCV results in the formation of small, mottled leaves that are severely crinkled at the edges. An additional primary consequence of TCV infection is a severe stunting of the plants and a marked reduction in the amount of storage root tissue produced (Figure 1), suggesting that viral infection might be causing significant interference with cellular metabolism and energy flow. Previous studies by others indicated that replication of TCV RNA likely occurs in membrane vesicles derived from mitochondria. It seemed likely, therefore, that if replication was occurring on the mitochondrial periphery, then the subsequent disruption of mitochondrial function might account for a significant component of the disease symptoms.

Electron micrographs of leaf tissue from mock and TCV-infected turnip leaves were used to confirm previous findings that TCV infection resulted in vesicularization of outer mitochondrial membranes in turnip (Figure 1B-D). The electron micrographs showed that only the outer mitochondrial membranes appeared to be affected by the TCV infection, and all other cellular membranes appeared normal. Close examination of the mitochondrial outer membrane vesicles showed that they did not contain virus particles, which accumulated to very high levels in the adjacent cytosol (Figure 1D). Chloroplast structure appeared to be normal in infected tissue (Figure 1B) when compared with leaves from mock inoculated plants. We next conducted gas exchange measurements of photosynthesis and respiration rates using an infrared gas analyzer in an effort to determine if the evident alterations in cellular morphology of the mitochondria caused a measurable reduction in the gas exchange rates. Unfortunately, gross measurements of photosynthesis and respiration rates of infected and uninfected leaves yielded variable and, therefore, unreliable results about the metabolic status of individually infected leaves (results not shown). Gross weight measurements of whole storage roots from mock and TCVinfected turnips at 40 days postinfection showed a $46 \%$ reduction in mass of TCV-infected storage roots, clearly confirming a marked impact of the viral infection on cellular metabolism which we attribute partially to mitochondrial disruption.

If mitochondrial function is stressed either by an increased energy demand or by physical disruption by viral infection, it is reasonable to hypothesize that expression of mitochondrial stress proteins might be altered. To test this, we used antibodies against four mitochondrial proteins known to be general indicators of stress; HSP70, cpn60, HSP22 and the alternative oxidase (see Materials and methods).

Mitochondria are difficult to isolate from green leaf tissue in sufficient amounts or purity to conduct more refined experiments. We therefore used a procedure developed for etiolated tissue (Hayes et al. 1991) to isolate mitochondria from turnip storage root tissue in an effort to characterize the effect of TCV infection more 

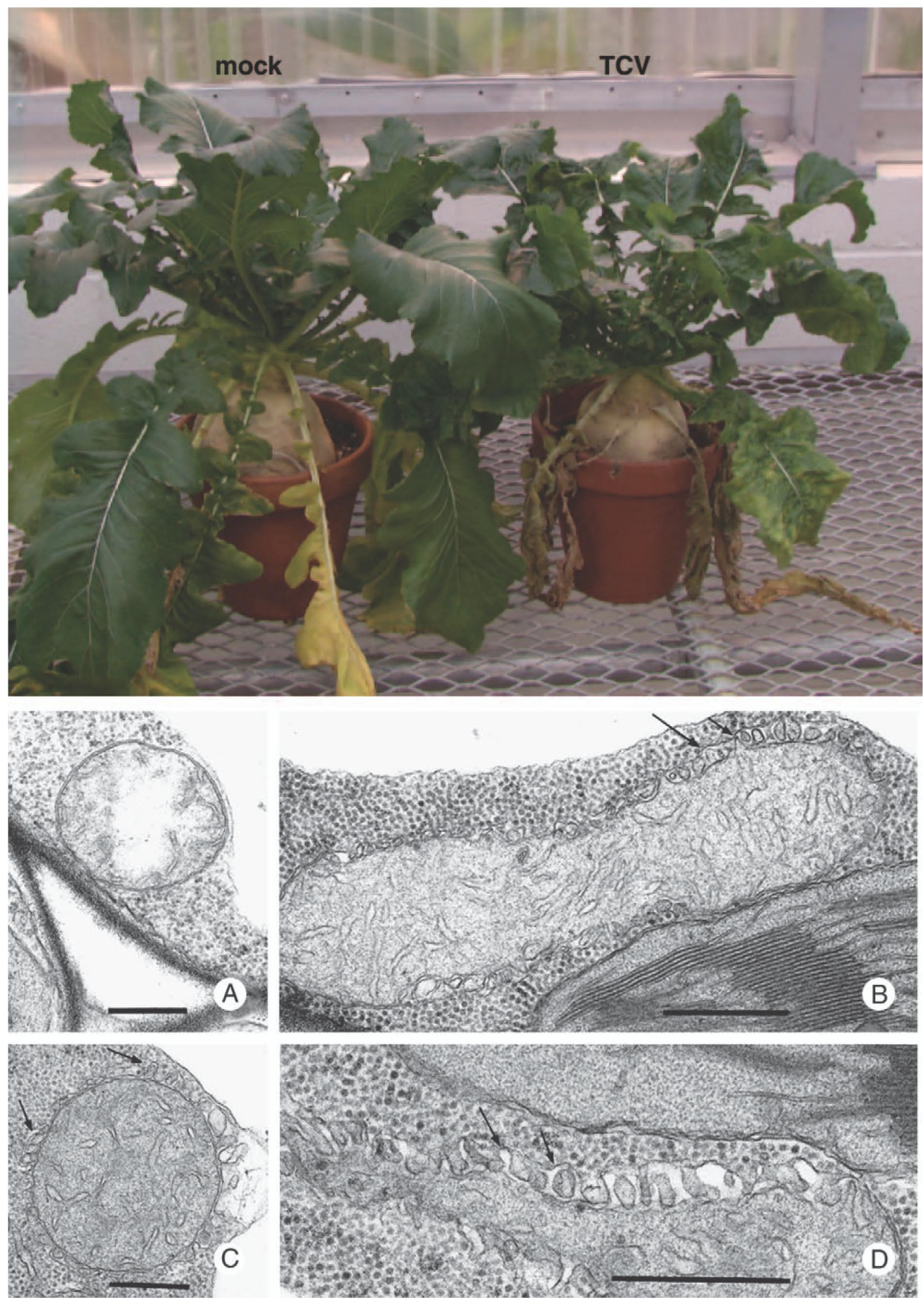

Figure 1. The effect of turnip crinkle virus (TCV) infection on turnip growth and subcellular morphology. The top panel shows 60-day-old turnips that are 30 days post-inoculated with a solution either containing no virus (mock) or containing the virus (TCV). The bottom panel contains electron micrographs of mitochondria from healthy (A) and TCV-infected turnip leaves (B, C and D). Bar, $500 \mathrm{~nm}$. Arrows indicate outer membrane vesicles.

directly on mitochondrial function and protein expression. Immunoblots of mitochondrial proteins isolated from the root tissue of mock and TCV-infected turnips were probed with various antibodies (Figure 2). Blots probed with antibodies to the viral protein p28 cross-reacted with two mitochondrial proteins in mock infected samples but clearly identify a protein of expected size for the p28 protein exclusively in the TCV-infected extracts (Figure 2, second set of panels). A putative degradation product of p28 was also detected. Similar results were observed using antibodies to the TCV coat protein (third set of panels). Some non-specific cross-reactivity 


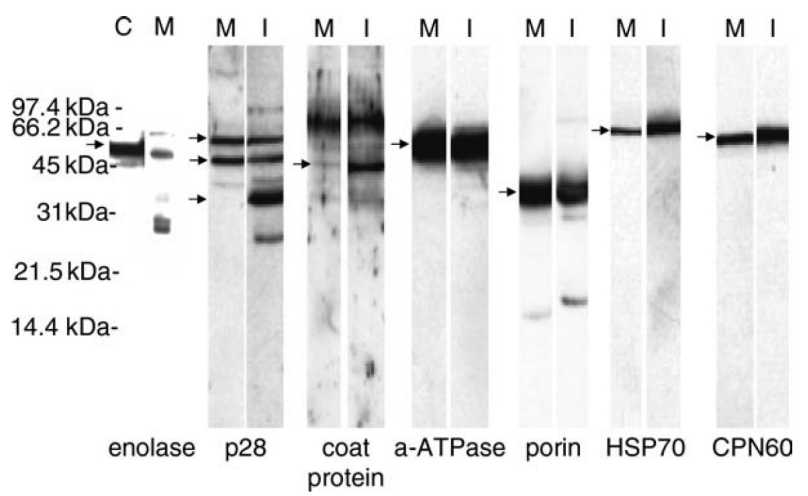

Figure 2. Immunoblot analysis of turnip root mitochondria. Immunoblots were loaded with $30 \mu \mathrm{g}$ per lane of mitochondria isolated from the roots of mock $(\mathrm{M})$ and infected (I) turnips. Contamination of isolated mitochondria with cytosolic proteins was evaluated with the cytosolic marker enolase as previously described by Lund et al. (1998). Panel 1 compares the enolase levels of cytosolic proteins (C) with those of isolated mitochondria (M). Immunoblots of mitochondria were probed with antibodies against turnip crinkle virus proteins (p28 and coat protein), protein marker for the inner mitochondrial membrane (a-adenosine $5^{\prime}$-triphosphatase), the outer mitochondrial membrane (porin) and two mitochondrial chaperone proteins (heat shock protein 70 and cpn60), followed by a chemiluminescent antibody and exposure to light detecting film. Immunoblots were equally loaded as seen by comparing two background proteins (50 and $60 \mathrm{kDa}$ ) detected in $\mathrm{M}$ and I mitochondria probed with antibodies against p28. Arrows point to proteins discussed in the Results section.

was observed with proteins in both the mock and infected samples, along with the TCV coat protein band only in the infected sample. Given that the TCV virion assembles in the cytoplasm in very high concentrations (Morris and Hacker 1994), the amount of coat protein observed in the mitochondrial preparations was likely because of non-specific binding of virions to mitochondrial membranes or contamination of the preparations with cytoplasmic debris. The cytosolic marker enolase was used to evaluate the level of cytosolic contamination of our mitochondrial preparations (Figure 2, first set of panels). The results show slight contamination of mitochondria with enolase supporting the view that some cytosolic proteins have bound non-specifically to the isolated mitochondria. Antibodies to specific mitochondrial proteins were then used to probe the same blots evaluated for p28 and coat protein. The level of the alpha subunit of the ATPase was used as a marker for the inner mitochondrial membrane (Figure 2, fourth set of panels). Porin was used as a marker for the outer mitochondrial membrane, and was reduced somewhat in mitochondria isolated from the TCV-infected tissue (Figure 2, fifth set of panels). In contrast, two mitochondrial chaperones located in the mitochondrial matrix, HSP70 and cpn60, showed elevated levels in infected preparations (Figure 2, sixth and seventh set of panels). Quantification of HSP70 and cpn60 levels indicated that

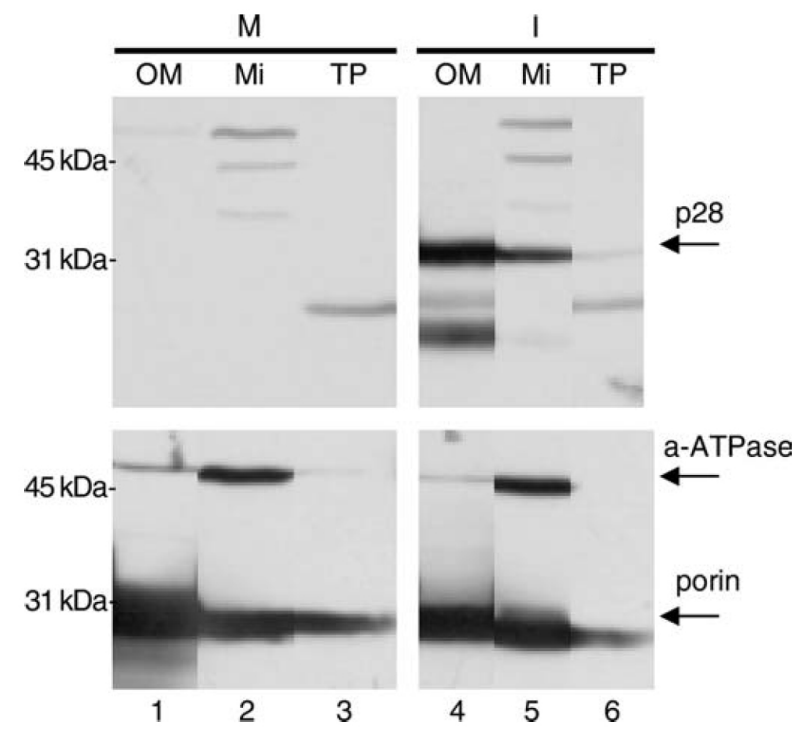

Figure 3. Immunoblot analysis of subcellular fractions from mock (M) and infected (I) turnip roots. Lanes were loaded with $30 \mu \mathrm{g}$ protein of outer mitochondrial membranes (OM, lanes 1 and 4), whole mitochondria (Mi, lanes 2 and 5) or total cellular proteins (TP, lanes 3 and 6). Immunoblots were first probed with antibodies against turnip crinkle virus p28 protein as described in Figure 2. The immunoblots were then stripped of antibodies and reprobed with a mix of protein marker antibodies for the inner mitochondrial membrane (a-adenosine 5'-triphosphatase) and the outer mitochondrial membrane (porin), following the method in Figure 2.

HSP70 increased 3.02-fold in infected tissue and cpn60 increased 1.55 -fold in infected tissue. These results support the view that TCV-dependent outer membrane vesicularization is perceived as a stress. Blots probed with alternative oxidase monoclonal antibodies (Elthon et al. 1989) or HSP22 monoclonal antibodies (Lund et al. 1998) indicated no detectable levels of alternative oxidase or HSP22 in either mock or infected mitochondria (data not shown).

To more firmly establish an association of p28 with mitochondria, equivalent loads of total cellular protein, isolated mitochondria and purified mitochondrial outer membranes were prepared for immunoblot analysis. The blots were first probed with antibodies to p28 and, after stripping, reprobed with antibodies against the alpha subunit of the ATPase (the inner mitochondrial membrane marker) and porin (the outer mitochondrial membrane marker). Immunoblots probed for ATPase showed, as expected, that the mitochondrial preparations were greatly enriched for inner membranes (Figure 3, lower panels). Probing with the porin marker showed that the outer membrane preparations were relatively devoid of inner membrane marker protein (alpha subunit of the ATPase), confirming that the fractionation procedure for isolating outer membranes worked as expected. The same blots probed with the p28 antibodies (upper panels) clearly show that p28 was most highly 


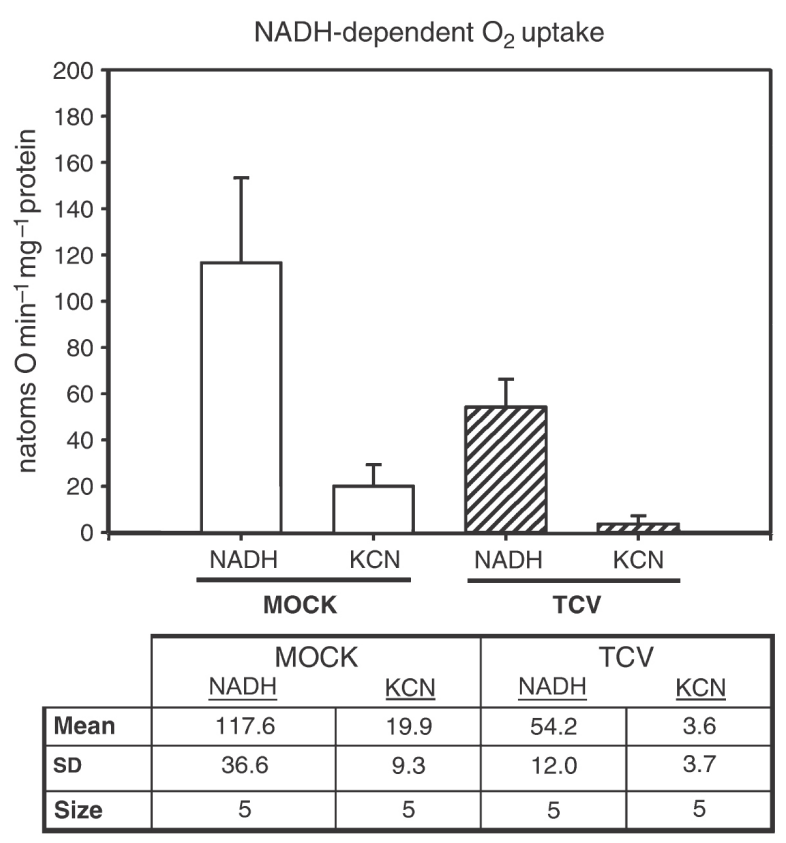

Figure 4. Nicotinamide adenine dinucleotide (reduced)-dependent oxygen uptake of mock and turnip crinkle virus-infected mitochondria. Measurements of oxygen levels were taken polarographically. Standard deviation is shown with an error bar.

enriched in the outer mitochondrial membrane fraction. The blots further showed that the mitochondrial proteins cross-reacting with the p28 antibodies were not outer membrane proteins. These results provide convincing evidence that p28 is localized to the outer mitochondrial membrane, consistent with the observed vesicularization of that membrane system.

Because we observed increased expression of two matrix-localized, mitochondrial stress proteins, HSP70 and cpn60, we anticipated that basic mitochondrial function would be measurably impacted by TCV infection. To start to address this question, we evaluated the activity of the mitochondrial electron transport chain using exogenous $\mathrm{NADH}$ and succinate as substrates. Intact mitochondria were isolated to conduct these assays to measure changes in $\mathrm{NADH}$-dependent oxygen primarily resulting from electrons entering the electron transport via the exogenous $\mathrm{NAD}(\mathrm{P}) \mathrm{H}$ dehydrogenases (Luethy et al. 1991, Rasmusson et al. 2004). For succinate-dependent oxygen uptake, succinate needs to be transported through the inner mitochondrial membrane for access to the succinate dehydrogenase complex which faces the matrix space. In addition, the succinate dehydrogenase complex needs to be activated through the addition of ATP prior to the addition of succinate. Exogenous $\mathrm{NADH}$-dependent oxygen uptake was observed to be decreased $54 \%$ in root mitochondria from TCV-infected plants (Figure 4). Cyanide was used to evaluate levels of the alternative oxidase present, with little capacity

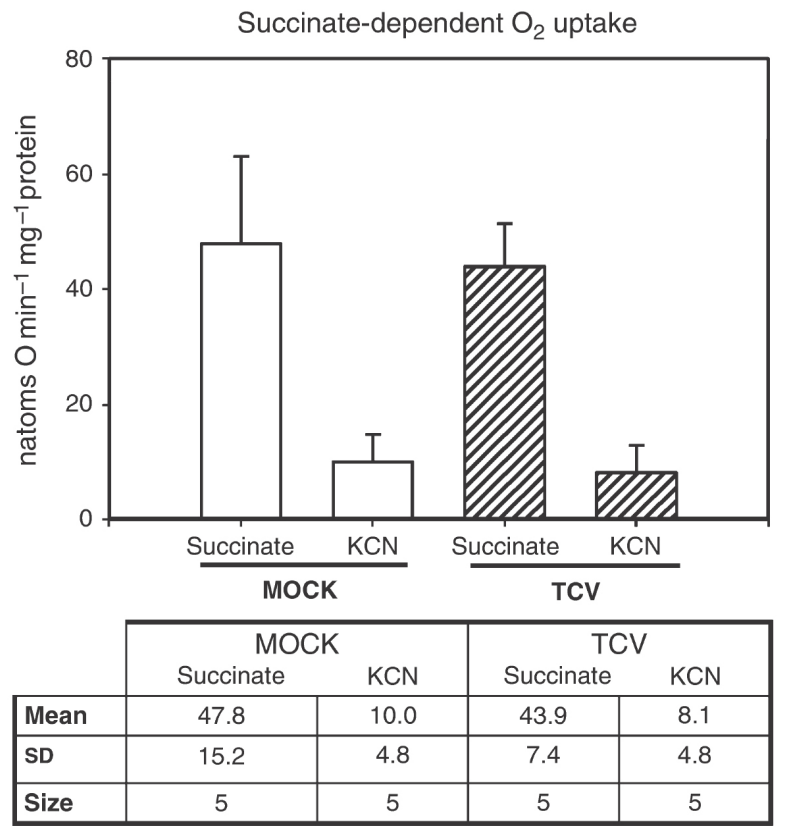

Figure 5. Succinate-dependent oxygen uptake of mock and turnip crinkle virus-infected mitochondria. Measurements of oxygen levels were taken as described in Figure 4. Standard deviation is shown with an error bar.

observed. When succinate was used as the substrate, succinate-dependent oxygen uptake was reduced by only $8 \%$ in root mitochondria from TCV-infected plants (Figure 5). Again, little alternative oxidase capacity was observed. The significant loss of exogenous NADH dehydrogenase activity could partially be responsible for the stunting and reduced plant mass associated with the viral infection.

\section{Discussion}

There have been only a few reports documenting the association of plant virus replication structures in association with host organelles such as mitochondria. One recent report demonstrated the external association of beet necrotic yellow vein virus particles with the outer membrane of mitochondria in infected cells but without apparent pathology (Erhardt, et al. 2001, Valentin et al. 2005). Several studies with plant tombusviruses have described the characteristic morphological changes associated with the targeting of replicase subunits in both plant and yeast mitochondria (Rubino et al. 2000, 2001) and a more recent report provided a model for membrane insertion of viral encoded replicase components in mitochondrial membranes (Weber-Lotfi et al. 2002). An important result from our study of isolated mitochondria is the confirmation that this organelle is the likely cellular location of the RNA replication apparatus of 
TCV, a plant carmovirus. It had been previously shown for several carmoviruses, including TCV and saguaro cactus virus, and the true tombusvirus, carnation Italian ringspot virus, that virus infection induced vesicularization of outer mitochondrial membranes (Russo and Martelli 1982). Our microscopy results confirmed those findings in TCV-infected turnips and also show that there was no obvious pathology associated with other cellular membrane systems. Analysis of viral proteins in isolated mitochondria from infected root tissues clearly demonstrated that p28 was preferentially localized to the mitochondrial outer membranes. The observation that the p28 protein is localized to the mitochondrial outer membrane suggests that mitochondrial targeting signals might be present in $\mathrm{N}$-terminal or internal sequences of both p28 and p88. It is known that outer mitochondrial membrane proteins are targeted differently than inner membrane or matrix proteins in that they may not require cleaved leader sequences for insertion (Wickner and Lodish 1985). Porin is an outer membrane protein that does not contain a hydrophobic region typical of integral membrane proteins (McBride et al. 1990). Instead, porin may intercalate into the membrane with a $\beta$-barrel structure. Porin was shown to associate with TOM20 in a HSP70-dependent manner (Komiya et al. 1997). A similar analysis of the p28 and p88 TCV proteins indicated that no obvious hydrophobic patches were present (data not shown). Ciuffreda et al. (1998) identified a putative mitochondria-targeting signal in $\mathrm{N}$ terminal amino acids spanning region $37-54$ of the p28 homolog of several carmoviruses including TCV. It has also been shown with carnation Italian ringspot tombusvirus, that p36, the functional homolog of p28, is alone responsible for inducing membrane vesicle formation in mitochondria in yeast (Rubino et al. 2000). In a more detailed study, this group failed to confirm the presence of a functional mitochondria-targeting signal, rather their results suggest that the replicase subunits anchor on the cytosolic side of the outer mitochondrial membrane before becoming invaginated inside of the vesicles (WeberLotfi et al. 2002). Our localization of p28 to isolated mitochondrial outer membranes would certainly support a similar model for TCV.

A second significant observation from our work was the increased synthesis of mitochondrial-related stress proteins as a consequence of infection. Both HSP70 and cpn60 were shown to be induced through immunoblot analysis of isolated mitochondrial preparations. Increased expression of these mitochondrial matrix chaperones supports the view that viral infection induces a general stress response. A few studies, but not many, have reported that viral-induced stress responses can have pronounced effects on respiration and mitochondrial function (Gilliland et al. 2003, Norman et al. 2004).
Additionally, it is well established that HSP70s play important roles as chaperones in the cellular trafficking of proteins. HSP70s are believed to play additional roles during stress, in protecting proteins from degradation during stress and in some cases, refolding proteins back to a functional state following stress. HSP70s are known to be involved in successful pathogen invasion. In the case of virus infection by pea seed borne mosaic virus, a HSP70 protein family was induced along the infection front as the virus infection moved from the pea embryo into the cotyledon (Aranda and Maule 1998). However, the increased expression of mitochondrial matrix HSP70 and cpn60 observed with TCV infection most likely reflects a stress response to mitochondrial damage. In this regard it was surprising to find undetectable levels of alternative oxidase and HSP22 proteins in mitochondria from both mock and infected tissues. Increased expression of both the alternative oxidase and HSP22 have been shown to occur with a variety of stresses (Lund et al. 1998, Simons et al. 1999) and with mutations affecting the mitochondrial electron transport chain (Karpova et al. 2002, Kuzmin et al. 2004). TCV replication associated with the mitochondrial outer membrane severely reduces exogenous $\mathrm{NADH}$ oxidation, and reduces the oxidation of succinate somewhat. These affects on the electron transport chain, along with the increased energy demand for viral synthesis, may explain the reduced root mass observed in infected turnips.

\section{Acknowledgments}

This work was supported in part by grants from Pioneer $\mathrm{Hi}$-Bred International and NSF-EPSCoR to T.E.E. and in part by a grant from the US Department of Energy (DEFG02-04ER15531) to T.J.M.

\section{References}

Aranda MA, Maule AJ (1998) Virus-induced gene shutoff in animals and plants. Virology 243: 261-267

Buck KW (1996) Comparison of the replication of positivestranded RNA viruses of plants and animals. Adv Virus Res 47: 159-251

Ciuffreda P, Rubino L, Russo M (1998) Molecular cloning and complete nucleotide sequence of galinsoga mosaic virus genomic RNA. Arch Virol 143: 173-180

Elthon TE, Mclntosh L (1986) Characterization and solubilization of the alternative oxidase of Sauromatum guttatum mitochondria. Plant Physiol 82: 1-6

Elthon TE, Nickels RL, McIntosh L (1989) Monoclonal antibodies to the alternative oxidase of higher plant mitochondria. Plant Physiol 89: 1311-1317

Erhardt M, Dunoyer P, Guilley H, Richards K, Jonard G, Bouzoubae S (2001) Beet necrotic yellow vein virus particles localize to mitochondria during infection. Virology 286: 256-262 
Garzon S, Strykowski H, Charpentier G (1990) Implication of mitochondria in the replication of Nodamura virus in larvae of the Lepidopera, Galleria mellonella (L.) and in suckling mice. Arch Virol 113: 165-176

Gilliland A, Singh DP, Hayward JM, Moore CA, Murphy AM, York CJ, Slator J, Carr JP (2003) Genetic modification of alternative respiration has differential effects on antimycin Ainduced versus salicylic acid-induced resistance to Tobacco mosaic virus. Plant Physiol 132: 1518-1528

Hacker DL, Petty ITD, Wei N, Morris TJ (1992) Turnip crinkle virus genes required for RNA replication and virus movement. Virology 186: 1-8

Hayes MK, Luethy MH, Elthon TE (1991) Mitochondrial malate dehydrogenase from corn. Plant Physiol 97: 1381-1387

Heckman NL, Elthon TE, Horst GL, Gaussoin RE (2002) Influence of trinexapac-ethyl on respiration of isolated wheat mitochondria. Crop Sci 42: 423-427

Heins L, Helga M, Angela S, Benz R, Schmitz U (1994) Biochemical, molecular, and functional characterization of porin isoforms from potato mitochondria. J Biol Chem 269: 26402-26410

Karpova OV, Kuzmin EV, Elthon TE, Newton KJ (2002) Differential expression of alternative oxidase genes in maize mitochondrial mutants. Plant Cell 14: 3271-3284

Komiya T, Rospert S, Schatz G, Mihara K (1997) Binding of mitochondrial precursor proteins to the cytoplasmic domains of the import receptors Tom70 and Tom 20 is determined by cytoplasmic chaperones. EMBO J 16: 4267-4275

Kuzmin EV, Karpova OV, Elthon TE, Newton KJ (2004) Mitochondrial respiratory deficiencies signal up-regulation of genes for heat shock proteins. J Biol Chem 279: 20672-20677

Li W (1996) Gene expression of turnip crinkle virus and characterization of the two movement genes. PhD thesis. University of Nebraska, Lincoln, NE

Luethy MH, Hayes MK, Elthon TE (1991) Partial purification and characterization of three $\mathrm{NAD}(\mathrm{P}) \mathrm{H}$ dehydrogenases from Beta vulgaris mitochondria. Plant Physiol 97: 1317-1322

Lund A, Blum PH, Bhattramakki D, Elthon TE (1998) Heat-stress response of maize mitochondria. Plant Physiol 116: 10971110

McBride HM, Millar DG, Li J, Shore GC (1990) A signal-anchor sequence selective for the mitochondrial outer membrane. J Cell Biol 119: 1451-1457

Morris TJ, Hacker DL (1994) Carmoviruses. Encyclopedia of Virology. Academic Press, London, pp 218-223

Nagy P, Pogany J (2000) Partial purification and characterization of cucumber necrosis virus and tomato bushy stunt virus RNA dependant RNA polymerases. Virology 276: 279-288

Norman C, Howell KA, Millar AH, Whelan JM, Day DA (2004) Salicylic acid is an uncoupler and inhibitor of mitochondrial electron transport. Plant Physiol 134: 492-501
Rajendran K, Pogany J, Nagy P (2002) Comparison of turnip crinkle virus RNA-dependent RNA polymerase preparations expressed in E. coli or derived from infected plants. J Gen Virol 76: 1707-1717

Rasmusson AG, Soole KL, Elthon TE (2004) Alternative NAD(P)H dehydrogenases of plant mitochondria. Annu Rev Plant Biol 55: 23-39

Rubino L, Russo M (1998) Membrane targeting sequences in tombusvirus infections. Virology 252: 431-437

Rubino L, Di Franco A, Russo M (2000) Expression of a plant virus non-structural protein in Saccharomyces cerevisiae causes membrane proliferation and altered mitochondrial morphology. J Gen Virol 81: 279-286

Rubino L, Weber-Lotfi F, Dietrich A, Stussi-Garaud C, Russo M (2001) The open reading frame 1-encoded (36K) protein of carnation Italian ringspot virus localizes to mitochondria. $J$ Gen Virol 82: 9-34

Russo M, Martelli GP (1982) Ultrastructure of turnip crinkle- and saguaro cactus virus-infected tissues. Virology 118: 109-116

Russo M, Di Franco A, Martelli GP (1981) The fine structure of cymbidium ringspot virus infections in host tissues. J Ultrastruct Res 82: 52-63

Schwartz M, Chen J, Janda M, Sullivan M, Boon J, Ahlquist P (2002) A positive-strand RNA virus replication complex parallels form and function of retrovirus capsids. Mol Cell 9: 505-514

Simons BH, Millenaar FF, Mulder L, Van Loon LC, Lambers $\mathrm{H}$ (1999) Enhanced expression and activation of the alternative oxidase during infection of Arabidopsis with Pseudomonas syringae pv tomato. Plant Physiol 120: 529-538

Song C, Simon AE (1994) RNA-dependent RNA polymerase from plants infected with turnip crinkle virus can transcribe (+)and (-)- strands of virus-associated RNAs. Proc Natl Acad Sci USA 91: 8792-8796

Valentin C, Dunoyer P, Vetter G, Schalk C, Dietrich A, Bouzoubaa $S$ (2005) Molecular basis for mitochondrial localization of viral particles during beet necrotic yellow vein virus infection. J Virol 79: 9991-10002

Weber-Lotfi F, Dietrich A, Russo M, Rubino L (2002) Mitochondrial targeting and membrane anchoring of a viral replicase in plant and yeast cells. J Virol 76: 10485-10496

Wei N (1990) RNA structure and function in the assembly and replication of turnip crinkle virus. PhD thesis. University of California, Berkeley, CA

White KA, Skuzeski JM, Li W, Wei N, Morris TJ (1995) Immunodetection, expression strategy and complementation of turnip crinkle virus p28 and p88 replication components. Virology 211: 525-534

Wickner WT, Lodish HF (1985) Multiple mechanisms of protein insertion into and across membranes. Science 230: 400-407 